\title{
Conditions for the Innovation Activities of Energy Sector Enterprises Shown on the Example of Mining Companies
}

\author{
Robert RANOSZ ${ }^{1)}$, Anna BLUSZCZ2), Dominik KOWAL ${ }^{3)}$
}

1) Ph.D., DSc, Eng.; AGH University of Science and Technology, Cracow, Poland; email: rranosz@agh.edu.pl
${ }^{2)}$ Ph.D., DSc, Eng.; Silesian University of Technology, Faculty of Mining, Safety Engineering and Industrial Automation, Gliwice,
Poland; email: anna.bluszcz@polsl.pl
3) Ph.D., Eng.; AGH University of Science and Technology, Faculty of Mining and Geoengineering, Cracow, Poland; email: dkowal@zarz.agh.edu.p

http://doi.org/10.29227/IM-2020-01-82

Submission date: $02-01-2020$ | Review date: 18-03-2020

\begin{abstract}
This paper discusses analysis of the innovative activities of mining companies in the years 2016-2018 against the background of innovation active industrial enterprises. In addition, reference is made in the article to the previous findings and research in the field of the level of innovation of mining companies. Despite the fact that the mining industry belongs to traditional industries and is considered to be not very innovative, it undertakes innovation activities necessitated by the need to bring the coal-fired power generation to market competitiveness, ensure industrial safety of miners and environmental protection. In recent years, mainly process innovations have been introduced, which is due to ongoing industry-restructuring processes. Despite the risks, the industry should recognise the opportunities in the current situation and try to use them for further innovations. The main objectives of the energy sector included in the Program for the hard coal mining sector in Poland should be pursued particularly through building new knowledge and innovation intensive competitive advantages. The implementation of clearly defined directions of innovation strategy in accordance with the provisions of the documents governing the Mining of Hard Coal section in Poland will enable its later functioning, country's energy independence and competitiveness of the national economy.
\end{abstract}

Keywords: innovation activities, mining companies, energy sector, product innovations, process innovations

\section{Introduction}

The coal markets crisis, arising as a result of instability and uncertainty of economic, socio-environmental and political conditions, affects both steam and coking coal. Deterioration of mining results and condition is mainly due to high production costs, oversupply of coal on the markets and low prices. An additional factor impacting the sector is the transition from the traditional to low-carbon economy as well as structural changes that are taking place in the energy market.

To recover from the deteriorating situation, the energy sector must rebuild its economic and financial structure and take advantage of the opportunities that arise in the Polish economy. One of them is "the high level of dependence of domestic primary energy demand, including electricity and heat, on coal fuels (over $50 \%$ of electricity is produced from hard coal (...)") [1]. This means that in the next decade, hard coal will be the main raw material for the energy mix. Substantial hard coal reserves in Poland are an opportunity for the country's energy independence and competitiveness of the national economy $[1,2,3,4,5,6,7,8]$. At present, the energy, energy resources and fuels demands are constantly increasing, which increases the importance of energy security.

Strengthening environmental protection requirements and reducing greenhouse gas emissions $[9,10,11,12]$, increasing competitiveness of other energy carriers on the domestic market (fossil fuels are replaced by renewable energy sources, with a significant share of wind, biomass and solar energy) as well as on European energy markets, including due to low oil and gas prices, means that the mining industry requires innovation activities. Nowadays, it is mainly innovative undertakings that affect the market competitiveness of an enterprise [13], therefore, in this case, to identify the sources of innovation and opportunities and threats related to their implementation is an unavoidable imperative of the managers [14].

The directions of innovation activity conducted by mining companies are specified in documents and acts regulating the functioning of mining sector in Poland. These include: "Energy Policy of Poland until 2030", "Climate and Energy Package" and "Program for the hard coal mining sector in Poland". The legal, political and environmental factors arising therefrom indicate that without innovation, the functioning of hard coal mining will be threatened in the long term. Only the right strategy adapted to these requirements will allow mining companies to survive in a turbulent environment [15].

The threats include, among other things: lack of investments or major delays in their implementation in entities of the energy sector based on hard coal, difficulties with simultaneous price reduction and improvement of coal quality, excessive number of IT systems and insufficient level of their integration resulting in "information chaos", low share of incentives in remuneration systems or no connection between the wage growth and workforce productivity, and an excessive fragmentation of pay components. While in the case of "information chaos" the staff try new solutions, e.g. in the form of new tools supporting the implementation of the strategy (Balanced Scorecard, Dashboard) [16, 17], in the case of remuneration systems the matter still has not been resolved, as discussed in more detail in $[18,19,20]$. 


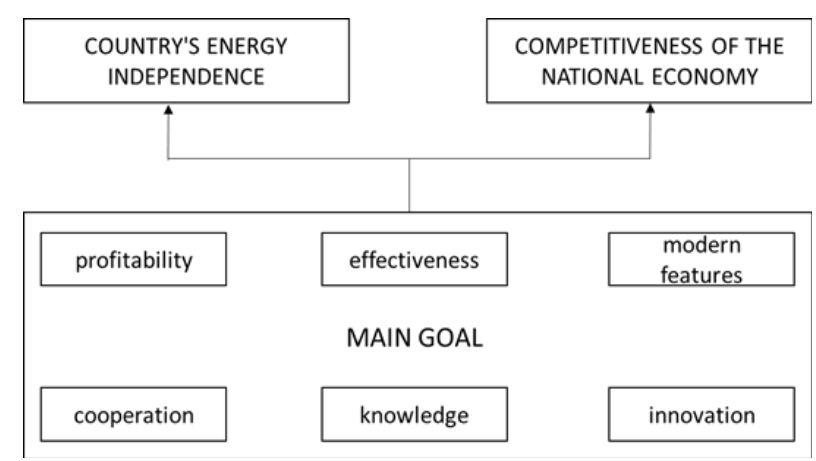

Fig. 1. Logical framework element. Source: [1]

Rys. 1. Element matrycy logicznej. Źródło: [1]

According to M. Stanisławski, "innovation in the mining industry has become such an important issue that there is a stronger need than in the past for it to be included in the strategic management process of a coal enterprise" [21]. Therefore, programmes supporting enterprise management are of great importance for innovations in the management processes.

The mining sector in Poland has been undergoing restructuring for many years in order to adjust its business structure and economic efficiency to the current market requirements $[22,23,24,18]$. The process of changes, in which mining companies are involved, should be treated as an opportunity to enable innovation $[25,26]$. In addition, they should explore innovation opportunities by cooperating with other entities in the scope of research and development activities [27].

\section{Directions of innovation activity in the energy sector}

Directions of innovation activity in the mining companies have been defined, among other things, in the "Programme for the hard coal mining sector in Poland". In the presented strategic analysis of the hard coal mining sector, the weaknesses include [1]:

- negative effects to the environment of the production process,

- inefficient organizational structures (prolongation of decision-making processes and low efficiency of information flow),

- $\quad$ excess of IT systems and its insufficient integration ('information chaos'),

- low optimization of work systems (insufficient efficiency of staff working time),

- low share of incentives in remuneration systems, no connection between the wage growth and workforce productivity, and an excessive fragmentation of pay components.

- low cost flexibility due to the high proportion of fixed costs,

- difficult economic and financial standing.

These are only selected elements from an extensive list of weaknesses that the hard coal mining industry is facing today. The directions for combating them are outlined in the main objective contained in the logical framework of the Program ..., comprising six elements: profitability, efficiency, modernity, innovation, knowledge and cooperation (Fig. 1).
"Only an economically healthy mining sector can ensure Poland's energy security" [1], therefore regaining and stabilizing liquidity, sales profitability and cost efficiency also related to investments are the most important objectives to be achieved by mining companies. The improvement of the financial situation enables implementation of subsequent elements specified in the logical framework. A very important element that has been very apparent recently is the "aging" of mining crews. Senior employees prevail in the staff age-seniority structure. They are experienced, but every year they leave the mines in large numbers. Newly recruited employees, on the other hand, lack experience, i.e. adequate knowledge and often also industry-specific education. Mining companies should support employees in the development of their skills and knowledge by expanding their training capacity with new technological and technical issues, with an emphasis on innovation. Nowadays, it is innovation that particularly affects the company's competitive position on the market [13], and its skilful combination with the implementation of other main objectives will also have a positive impact on the country's energy independence.

\section{Innovation activity in the mining companies}

Previous analyses regarding the level of innovativeness of Polish mining companies over the period of 2006-2008 indicated a definitely low share of mining sector in creating innovations compared to other industrial and service sectors. They confirmed the authors' claims that the traditional industries are not very innovative [28]. Over the period of 2009-2011, exploration companies recorded a higher share of innovation activity in their sector (50\%) than innovative companies in the industry in the total number of these entities (45.7\%) [21]. In 2012, results of research carried out as part of the implemented project were published, the purpose of which was to analyse innovations occurring in the mining industry in terms of their type and factors determining the innovation development in the mining companies [27]. The research indicated the occurrence of process, product and marketing innovations, however, they were carried out only in one mining company, where employees most often initiated innovation activities. Analyses of the level and structure of investment outlays in mining companies were also the subject of other works and articles [29, 30, 31, 32].

Since then, the share of mining companies launching innovations has been steadily increasing, with large mining 


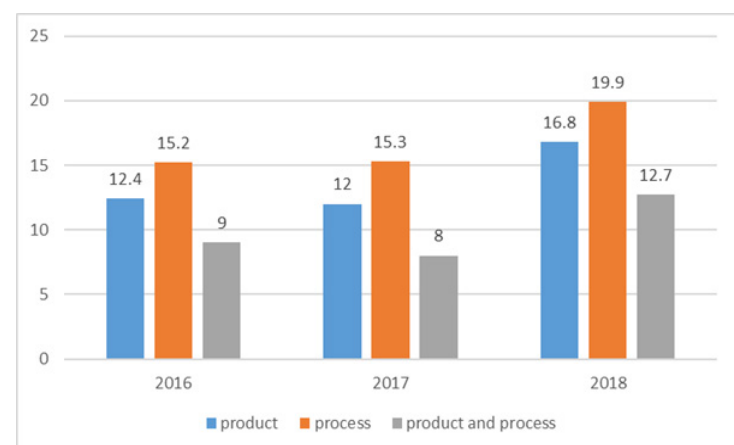

Fig. 2. Innovative industrial enterprises in 2014-2016 by types of innovation [\%]. Source: own elaboration based on [33, 34, 35] Rys. 2. Innowacyjne przedsiębiorstwa przemysłowe w latach 2014-2016 według rodzajów innowacji [\%]. Źródło: opracowanie własne na podstawie [33, 34, 35]

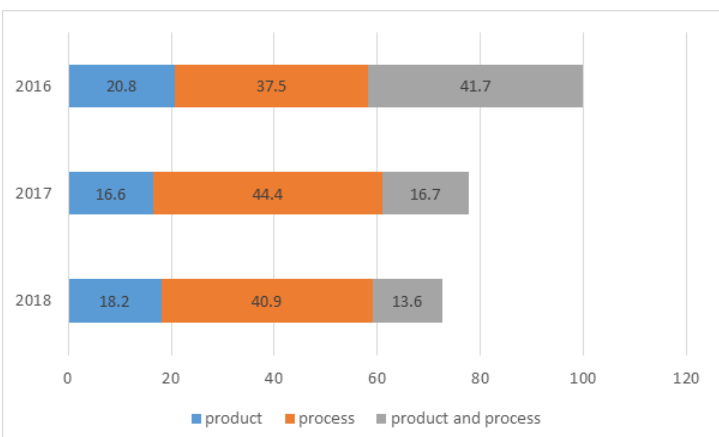

Fig. 3. Innovations generated in enterprises from the hard coal and lignite mining section by type in 2016-2018 [\%]. Source: own elaboration based on [33, 34, 35] Rys. 3. Wprowadzane innowacje w przedsiębiorstwach z działu Wydobywanie węgla kamiennego i węgla brunatnego według rodzajów w latach $2016-2018$ [\%]. Źródło: opracowanie własne na podstawie [33, 34, 35]

companies (employing over 249 employees) being the most innovative ones. Mining companies that are innovation active are those that (according to Statistics Poland, GUS) generated at least one innovation (product or process innovation or implemented at least one innovative project) in the examined period. Research on innovation activity among industrial enterprises shows that in each of the three years preceding the research the share of enterprises that generated process innovations was higher than the share of enterprises with product innovations. Comparing the period of 2016-2018, the percentage of enterprises that generated an innovation process was significantly higher by 4.7 percentage points amounting to $19.9 \%$ in 2018 , while in the case of product innovations the figure increased by 4.4 percentage points amounting to $16.8 \%$ (Fig. 2).

Due to the specific nature of mining companies and the homogeneity of the manufactured product it is hard to provide product innovations, which is why sources of innovation were sought primarily in implemented processes. The research of Statistics Poland (2016-2018) confirms the dominance of process innovations in the mining sector. In the mining of hard coal and lignite section, the generation of innovations by type is presented in Fig. 3. Each year, the percentage of generated process innovations is the highest, namely $37.5 \%$ (2016), $44.4 \%$ (2017) and 40.9\% (2018), respectively.

According to the division adopted by Statistics Poland - a high percentage of mining companies generated organisational innovations as part of process innovations, which is associated with the ongoing restructuring processes of the industry, which has been carried out for many years. Such innovations must result from strategic decisions taken by management.
Focusing on process innovations it is noted that the processes in mining companies are classified according to three categories [36] (Tab. 1):

- management processes,

- essential processes,

- $\quad$ supporting processes.

The listed processes are subordinated to the main mining and processing activity, which is coal production. This process is conceived as a "set of interrelated or interacting activities that transform inputs into outputs" [37].

In accordance with the directions of innovation activity in mining companies, generating innovations in all processes (management, essential and supporting) is aimed at reducing mining costs, which results from a possible reduction of the coal price. Such activities take place mainly through process automation technology and its computerization. The need to automate the production and modify hard coal mining systems requires the commitment of the company's innovative potential and use of new technologies.

On the other hand, implementing product innovations by mining companies is aimed at improving the quality of extracted coal. Therefore, the origins of product innovation can be found in the capacities of shaping the basic parameters of hard coal (calorific value, total moisture, ash and sulphur content), which must be adapted to the requirements of coal consumers. An appropriate enrichment technology enables production of specific coal grades, however, their quality depends on two factors. The first one is the mining system used, the second that is more important are the properties of coal in the seams. Precisely due to natural, geological and mining 
Tab. 1. Examples of processes implemented in mining companies. Source: own elaboration based on [28, 37]

Tab. 1. Przykładowe procesy realizowane w przedsiębiorstwach górniczych. Źródło: opracowanie własne na podstawie [28, 37]

\begin{tabular}{|c|c|}
\hline Process type & Process name \\
\hline Management processes & $\begin{array}{l}\text { - Technical and economic planning } \\
\text { - HRM } \\
\text { - Internal and external communication } \\
\text { - Improvement of the safety management system } \\
\text { - Strategy design }\end{array}$ \\
\hline Essential processes & $\begin{array}{l}\text { - Customer needs identification } \\
\text { - Production planning and design } \\
\text { - Opening works } \\
\text { - Preparatory works } \\
\text { - Reinforcing works } \\
\text { - Decommissioning works } \\
\text { - Vertical transport } \\
\text { - Coal enrichment } \\
\text { - Expedition }\end{array}$ \\
\hline Supportive processes & $\begin{array}{l}\text { - Data analysis } \\
\text { - Horizontal transport } \\
\text { - Infrastructure and working environment } \\
\text { - Overseeing } \\
\text { - The measurement and monitoring apparatus } \\
\text { - Procurement } \\
\text { - Expedition }\end{array}$ \\
\hline
\end{tabular}

conditions that have not been foreseen, the innovative potential of mining companies in the scope of product innovation is significantly reduced.

Advancing the development of process innovations, as mining companies mainly generate this, is possible thanks to cooperation with other enterprises or institutions with respect to innovative operations.

\section{Examples of innovation activities in the mining}

The management boards of Polish hard coal mining companies implement investments aimed at the optimal use of resources underground, including the extension of the assets exploitation through, among others, operating in thin seams, or minimizing the resources left in the deposit. In JSW S.A. mines modern ploughing technology has been used, thanks to which operation in seams considered some time ago as economically unjustified, can be carried out profitably these days. Centre for Advanced Data Analysis allows, among others, digital modelling of the deposit in order to optimize the production process and efficient resource extraction. Other raw materials are extracted in the mining company as well. Methane, as a high-energy fuel released from the deposit, will be used to power boiler plants in schools in the Gierałtowice municipality. The company is conducting research on innovative solutions to increase the degree of methane capture, also from the ventilation air exhausted through mining shafts (in 2018. PLN 25 million was allocated for this purpose, for the construction of a new demethylation station in Ruch "Zofiów$\mathrm{ka}$ ", and expansion of the demethylation station Ruch "Szczygłowice" and "Knurów"). The captured methane will be used in polygeneration systems with a total capacity of $48 \mathrm{MW}$ for the production of electricity, heat and cold).

In 2018, JSW S.A., PG Energy Capital Management and JSW Innovations signed a letter of intent on a joint undertaking to produce pellets based on CoalTech company technology using coal sludge. Another example of an innovative solution is the modern coking plant "Przyjaźń" that is a leader in the implementation of ISO standards throughout the Polish industry, including a pioneer in the introduction of the ISO 50001, confirming commitment to concern for the level of energy consumption, and thus the impact on the environ- ment. The company is currently working on exploring the possibilities of using hydrogen that accounts for $50 \%$ of the by-product of the coking process to develop clean hydrogen technologies used in the "Zero Emissions Public Transport" programme, a result of which 3.5 thousand of alternative fuel buses are expected to be produced in the next 10 years . Innovative materials such as carbon fibers, adsorbents and carbon nanotubes are further projects. The highest potential in lightweight construction is guaranteed by carbon fibers and it is estimated that they will constitute over $45 \%$ of future composite applications. On the other hand, carbon absorbents are used to remove impurities from the liquid or gaseous phase, as catalysts or as carriers used for the storage of gases. The carbon nanostructures outlined are used in the automotive industry, power engineering, chemistry and electronics $[38,39]$.

\section{Cooperation on innovation activities}

Cooperation with respect to innovative operations is based on cooperation with other entities and is an important element of every enterprise's activity. This type of cooperation in the mining industry is particularly important mainly because of the low level of innovation in the Polish mining companies, resulting from industry conditions and State ownership. A lack of sources of funding can be perceived as the fundamental barrier to innovation in the mining industry [28].

According to statistical analyses of GUS over the period 2016-2018, 25.4\% of innovation active industrial enterprises cooperated within the framework of innovation activity [33, $34,35]$.

Taking into account PKD sections, over the period 20162018 the highest positions (1-3 and 15) in the study were taken by the divisions from section B - Mining and quarrying (Fig. 4). Cooperation with respect to innovative operations was most often undertaken by enterprises belonging to the mining of metal ores (100\%) and mining of crude oil and natural gas (100\%) sectors. Mining of Hard Coal and Lignite section was ranked third (72.7\%). Position 15 was taken by the section Other mining and quarrying (30.3\%).

Segments from section E - Water supply, were also quite high on the list; sewerage and waste management and remediation activities, in particular Remediation (60\%; place 4 ) 


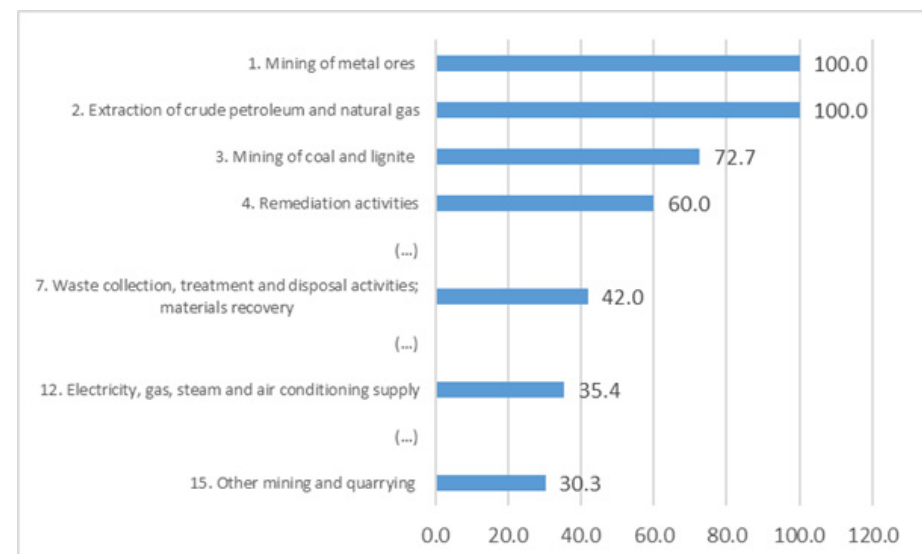

Fig. 4. Selected innovation active industrial enterprises over the period 2016-2018 sorted by some PKD divisions [\%]. Source: own elaboration based on $[33,34,35]$

Rys. 4. Wybrane przedsiębiorstwa przemysłowe aktywne innowacyjnie w latach 2016-2018 według wybranych działów PKD [\%]. Źródło: opracowanie własne na podstawie $[33,34,35]$

and Waste management and Recovery of raw materials (42\%; place 7). Section D - Production and supply of electricity, gas, steam, hot water and air for air conditioning systems took 12th place.

Cooperation with respect to innovative operations enables mining companies, above all, to get a wider access to knowledge and new technologies. It reduces costs and promotes the exchange of experience and knowledge - a combination of theory and practice. It is reflected in an active participation in joint projects with other enterprises or scientific bodies (S. Staszic AGH University of Science and Technology in Kraków, Silesian University of Technology, University of Economics in Katowice, Central Mining Institute and others). Such cooperation should preferably be prospective and longterm in nature.

\section{Discussion and conclusion}

The analysis of the current state of innovation level of mining and energy enterprises shows that the companies mainly focus on their current operations. The main aspects to focus on include: increased customer satisfaction, cost optimization, increased efficiency and effectiveness. Considering these targets it has to be concluded that they are of operational importance, however, it would be appropriate to consider the diversification of the electricity sources generated by indigenous companies in the context of a global trend (especially considering the EU policies) towards the complete elimination of pollution caused by the burning of fossil fuels. Poland has a specific potential to generate both electricity and heat from RES, so perhaps it would be justified to direct some of the innovation activities to the alternative energy sources that are within the scope of Poland's capabilities. Such action implemented well in advance could to some extent guarantee several key points that are required and at the same time expected by Polish society and the economy. These undoubtedly include: energy security, employment stability in the energy and mining sectors, and environmental protection. Such activities should be supported and financed not only by the industry concerned but also by the State. An important innovation aspect aimed at energy security and employment stability is undoubtedly conducting research on technologies that will make Poland independent from foreign enterprises.

This paper was supported by the AGH University of Science and Technology [No. 16.16.100.215]. 


\section{Literatura - References}

1. Program for the hard coal mining sector in Poland, Ministerstwo Energii, Warszawa 2018. [in Polish]

2. Ranosz, R. Mining and its importance in the global economy. Mineral Resources Management 2014, 30 (1), 5-20. http://doi.org/10.2478/gospo-2014-0003.

3. Jonek-Kowalska I. Challenges for long-term industry restructuring in the Upper Silesian Basin. What has Polish coal mining achieved and failed from a twenty - year perspective? Resource Policy 2015, 44(C),135-149.

4. Brzychczy E. An overview of data mining and process mining applications in underground mining. Journal of the Polish Mineral Engineering Society 2019, R.21 nr 1,pp. 301-314.

5. Kowal B., Kustra A. Sustainability reporting in the energy sector, E3S Web of Conferences 2016, 10, 00129.

6. The balance of mineral resources deposits in Poland for the years 2014-2018, PSG, Warszawa 2018.

7. Manowska, A.; Rybak, A. The future of hard coal compared to other energy carriers. 4th Polish Mining Congress-Session: human and environment facing the challenges of mining. IOP Conference Series-Earth and Environmental Science 2018, vol. 174, Article Number: 012007, DOI: 10.1088/1755-1315/174/1/012007.

8. Manowska, A.; Mazurek, M. Prospects for development and hard coal economy limitations in the context of ensuring national energy security. Mining - Prospects and Threats: Coal - Cheap, Clean Energy and Workplaces. IOP Conference Series-Earth and Environmental Science 2018, vol. 198, Article Number: UNSP 012005, DOI: 10.1088/1755-1315/198/1/012005.

9. Bluszcz, A. European Economies in terms of energy dependence. Quality and Quantity 2017, vol.51. no. 4 15311548.. https://doi.org/1007/s11135-016-0350-1.

10. Bluszcz, A. The emissivity and energy intensity in EU countries - consequences for the Polish economy. Conference proceedings Energy and Clean Technologies. Recycling, Air Ppollution and Climate Change, Sofia 2018, STEF92 vol. 18, iss. 4.2, 631-638. https://doi.org// 10.5593/sgem2018/4.2/S19.081.

11. Kijewska, A.; Bluszcz, A. Analysis of greenhouse gas emissions in the European Union with the use of agglomeration algorithm. Journal of Sustainable Mining 2016. Vol. 15 iss.4 133-142 DOI 10.1016/j.jsm.2017.02.001.

12. Kijewska, A.; Bluszcz, A. Research of varying levels of greenhouse gas emissions in European countries using the k-means method. Atmospheric Pollution Research 2016, Vol. 7 iss. 5, s. 935-944. DOI 10.1016/j.apr.2016.05.010.

13. Kowal, D.; Kowal, B. Finansowanie przedsiębiorczości innowacyjnej w Polsce, W: Innowacyjność w działalności gospodarczej, Iwaszczuk N. (red.), Wydawnictwo IGSMiE PAN, Kraków 2019. [in Polish]

14. Turek, M.; Jonek-Kowalska, I.; Ganszczyk, Z. Determinanty innowacyjności w przedsiębiorstwach górniczych, Zeszyty Naukowe Politechniki Śląskiej, Organizacja i Zarządzanie 2011, z. 55, 159-172. [in Polish]

15. Rybak, A.; Manowska, A. The forecast of coal sales taking the factors influencing the demand for hard coal into account. Mineral resources management 2019, vol. 35 iss. 1, 129-140. DOI: 10.24425/gsm.2019.128203.

16. Kowal, B.; Karkula, M.; Kowal, D. Selected aspects of the implementation of a coal mining company strategy using the Balanced Scorecard [monography], ISBN: 978-83-7464-881-3. Wydawnictwa AGH, Kraków 2016.

17. Kowal, B.; Bąk, P.; Sukiennik, M. Dashboard - a system of measures supporting the enterprise in achieving its goals. Journal of the Polish Mineral Engineering Society 2018; ISSN 1640-4920, R. 20 nr 2, 41-46.

18. Kowal, B. New trends in remuneration schemes for underground workers in hard-coal mines, Wydawnictwa AGH, ISSN 0867-6631, Kraków 2019. [in Polish]

19. Kowal, B.; Wiśniowski, R.; Ogrodnik, R.; Młynarczykowska, A. Selected elements of a safe work environment in hard coal mines in the Polish mining sector. Journal of the Polish Mineral Engineering Society 2019, ISSN 16404920, R. 21 nr 2, 215-223. http://www.potopk.com.pl/Full_text/2019_full/IM\%202-2019-a35.pdf.

20. Kowal, B. Analysis of the comfort life and work in the assessment of the occupational group of employees in the energy sector on the basis of a mining company, E3S Web of Conferences: Energy and fuels 2018, ISSN 2267-1242, vol. 108 art. no. 02016, 1-11. https://www.e3s-conferences.org/articles/e3sconf/pdf/2019/34/e3sconf_ef18_02016. pdf.

21. Stanisławski, M. Selected aspects of the innovative activities of mining enterprises in the years 2009-2011, Akademia Finansów i Biznesu Vistula - Warszawa 2013, 3(37), 53-69. [in Polish]

22. Manowska, A.; Nowrot, A. The importance of heat emission caused by global energy production in terms of climate impact. Energies 2019, vol. 12 iss. 16, 1-12. https://doi.org/10.3390/en12163069.

23. Ranosz, R. Analysis of the structure and cost of capital in mining enterprises. Mineral Resources Management 2017, ISSN 0860-0953. vol. 33 iss. 1, 77-91. 
24. Dubiński, J.; Turek, M. Chances and threats of hard coal mining development in Poland - the results of experts research. Archives of Mining Sciences 2014, 59 (2), 395-411. http://doi.org/10.2478/amsc-2014-0028.

25. Bielski, I. The course and conditions of innovative processes. Biblioteka Menedżera i Służby Pracowniczej, Zeszyt 187. Oficyna Wydawnicza Ośrodka Postępu Organizacyjnego Sp. z o.o., Bydgoszcz 2000. [in Polish]

26. Durlik, I. Innovative changes as part of the enterprise restructuring strategy, Instytut Organizacji i Zarządzania w Przemyśle „ORGMASZ”, Ekonomika i Organizacja Przedsiębiorstwa 1998, nr 5. [in Polish]

27. Święcicka, Z. Innovations in mining enterprise management, Contemporary Management quarterly 2012, vol. 2, 121-130. [in Polish]

28. Jonek-Kowalska, I.; Turek, M. Determinants of efficiency in hard coal mines in Poland in current market and geological and mining conditions, Journal of the Polish Mineral Engineering Society 2016, R. 17 nr 2, 81-90. [in Polish]

29. Ogrodnik, R.; Kowal, B. The level and structure of investment outlays in mining companies, Journal of the Polish Mineral Engineering Society, ISSN 1640-4920, 2019 R. 21 nr 2, 207-214.

30. Ogrodnik, R.; Kęsek, M. Analysis of the amount of investment outlays of mining enterprises, Marketing i Rynek ; ISSN 1231-7853, 2018 R. 25 nr 9, 746-759. [in Polish]

31. Mieszaniec, J.; Ogrodnik, R. The scope of innovative activities that bring environmental benefits to mining companies, W: Polityka zrównoważonego i zasobooszczędnego gospodarowania, Graczyk A. (red.), Wydawnictwo Uniwersytetu Ekonomicznego we Wrocławiu, Wrocław 2013. [in Polish]

32. Franik, T. Evaluation of the use of expenditures for innovation in the mining industry, Przegląd górniczy 2015, vol.8, 19-22. [in Polish]

33. Innovative activity of enterprises in the years 2014-2016, Statistical analyses, Statistics Poland, Statistical Office in Szczecin, Warszawa, Szczecin 2017. [in Polish]

34. Innovative activity of enterprises in the years 2015-2017, Statistical analyses, Statistics Poland, Statistical Office in Szczecin, Warszawa, Szczecin 2018. [in Polish]

35. Innovative activity of enterprises in the years 2016-2018, Statistical analyses, Statistics Poland, Statistical Office in Szczecin, Warszawa, Szczecin 2019. [in Polish]

36. Nowosielski, S. (ed.) Process approach in organizations. Wydawnictwo Uniwersytetu Ekonomicznego we Wrocławiu, Wrocław 2009. [in Polish]

37. Kowal, B., Ranosz, R., Karkula, M., Kowal, D. Process Management in Hard Coal Mining Companies, Journal of the Polish Mineral Engineering Society 2018, iss. 2 (42), 111-116, http://doi.org/10.29227/IM-2018-02-14.

38. Biuletyn PRE_COP24 Polska droga do czystego środowiska. Katowice 2018.

39. Bluszcz, A. Circular economy initiatives in the mining companies in Poland. Bezpieczne i efektywne górnictwo. Wybrane zagadnienia. Praca zbiorowa. Bańko P. (ed.). Wydaw. Politechniki Śląskiej, Gliwice 2020, p. 44-52. [in Polish] 


\section{Uwarunkowania działalności innowacyjnej przedsiębiorstw sektora energetycznego \\ na przykładzie przedsiębiorstw górniczych}

Artykuł prezentuje analizę działalności innowacyjnej przedsiębiorstw górniczych w latach 2016-2018 na tle aktywnych innowacyjnie przedsiębiorstw przemystowych. Ponad to w artykule odniesiono się do wcześniejszych analiz i badań z zakresu poziomu innowacyjności przedsiębiorstw górniczych. Pomimo, że branża górnicza przynależy do tradycyjnych branż przemysłu i uważana jest za mało innowacyjna to podejmuje działania innowacyjne, których konieczność wynika z potrzeby zapewnienia konkurencyjności energetyki węlowej, bezpieczeństwa pracy górników oraz ochrony środowiska. W ostatnich latach wprowadzane są głównie innowacje procesowe, co wynika z trwających nadal procesów restrukturyzacji branżowej. Pomimo istniejacych zagrożeń, branża powinna zauważać szanse w obecnej sytuacji i starać się ją wykorzystać do wprowadzenia kolejnych innowacji. Konieczne staje się realizowanie głównych celów sektora energetycznego zawartych w Programie dla sektora górnictwa wegla kamiennego w Polsce poprzez budowanie nowych przewag konkurencyjnych opartych w szczególności na wiedzy i innowacyjności. Realizacja jasno wyznaczonych kierunków strategii innowacyjnej, ujętych $w$ dokumentach regulujacych funkcjonowanie górnictwa węgla kamiennego $w$ Polsce pozwoli na dalsze jego funkcjonowanie, niezależność energetyczną kraju i konkurencyjność gospodarki narodowej.

Słowa kluczowe: działalność innowacyjna, przedsiębiorstwa górnicze, sektor energetyczny, innowacje produktowe, innowacje procesowe 